WŁODZIMIERZ OKRASA

Cardinal Stefan Wyszynski University

in Warsaw, Poland

\title{
MIGRATION AND THE STATUS OF 'STRANGER' IN A HOMOLOGOUSLY INTERPRETED LOCAL SPACE
}

\begin{abstract}
The aim of this article is empirical exploration of the dependence of the status of a 'stranger' on the local and social context. In that context $\mathrm{s} / \mathrm{he}$ acts as a participant of migration process that represents dynamics of the locally relativised attributes of the environment / 'localisation'. The thesis statement concerns the interference of constitutive ecological, organizational, cultural and symbolic dimensions into the social space. Thus the paper verifies validity of the subsequent hypotheses that 'environment' (coexistent attributes, fields, characteristics) that constitute the configuration of the 'homological structures' as defined by Pierre Bourdieu and specific for particular local communities influences perception and attitude towards a stranger. The operationalisation of such complex constructs, along with the contextualisation of the migration phenomenon involving the stranger-environment relationship, leads to the adoption of an interdisciplinary research perspective that in addition to sociology includes geographic economy, demography and spatial statistics. The analysis of the aforementioned dependencies requires a multi-source database from various surveys and administrative data (the Local Data Bank of the Statistics Poland). The results of the analyses confirm that the main determinant of the attitude towards a stranger (as a migrant) and their status in the changing environment is the local social space (interpreted in a homologous way).
\end{abstract}

KEYWORDs: migration process, stranger, Bourdieu's social space, local deprivation, subjective well-being 


\section{INTRODUCTION}

\section{PRoblem AND CONTEXT}

The classic, Simmellian interpretation of a stranger in sociology emphasizing its interactively defined position (status) in the social space, built upon the physical space (Urry, 2005) - including the dialectical way, in which the inherited external space influences life experiences (Frisby, 1994; Okrasa, 2016) - can be extended towards the conceptualization of the interdependence of these spaces in the sense of Pierre Bourdieu (1990) as homologous constructs both in structural and functional aspects. [Contrary to the relations between subspaces understood in the topological way according to Bourdieu, Simmel's 'sociology of space' uses opposite attributes like separation and connection, distance and proximity, boundaries and openings (Frisby, 1994, p.1).] Bourdieu-style theorizing suggests understanding of the migration process in terms of the transformation of the status of stranger as a participant in this process, along with the factors of a way he is perceived and of attitudes towards him. It provides therefore a framework for the operational formulation of the research problem, both in conceptual and methodological aspects. On the one hand, it enables the problem to be contextualized by incorporating multidimensional interpretations of local space; on the other, it highlights the limitations and reductions necessary in the operationalisation of concepts found in theoretical conceptualizations. Mentioned multidimensionality is typically specified along (i) ecological components, represented by a set of appropriate indicators; (ii) "organisational and social" components, with the institutional subspace of the recognisable 'actors' / agents (inhabitants, administration, civil society etc.); and (iii) "cultural and symbolic" components, with mental and psychic subspaces, represented by i.a. emotional attitude to 'place' and identification with it, measured in particular with the specific measure of a subjective well-being (e.g. Jensen et al., 2020).

Such conceptualisation resonates with the definition of local community adopted usually in the empirical analyses using the ideal-type maximin formula as a spatially separated whole with properties similar to above-mentioned 
types of components. An example would be the three-dimensional calibration of attributes on the appropriate coordinates proposed by Bhattacharyya (2004): $x$ - common ecology (excluding online communities etc.); $y$ - social organization (forms of action based on social capital); $z$ - shared cultural and symbolic meaning (including institutional and religious, community' values). The local community is 'strong' or 'weak' in the sense of the position (scale) on the dimensions that create configuration - that can also be reflected in its coherence, affecting the attitude towards a stranger (Okrasa, 2016).

In methodological terms a geographically identifiable local community can be an operationally useful concept that is analogous to Bourdieu's habitus responsible for the transposition between social space (with its subspaces) and physical space - and also acts as an integrator of the components of space. As an administrative and territorial unit, local community provides a natural frame of reference for the phenomenon of migration - including transnationalisation - allowing the interpretation of the migration process as a dynamic transformation of the status of 'migrant' in space: From social position in 'their own' community to positions taken in the course of changes of 'new' local communities, while using Bourdieu's terminology, according to which "... the space of social positions is translated into the space of 'positions taken' through the space of disposition (or habitus).” Bourdieu (1996: 14). Such a conceptualization of social space, useful in the substantive part of problem formulation, is subject to a fundamental re-interpretation in the methodological layer - as a metaphorical version of spatial integration - and a significant reduction in the course of operationalisation of concepts and creation of appropriate variables. This specification is illustrated by sample questions, e.g. whether local communities with a given level of (under-)development (local deprivation) induce similar patterns of attitudes towards a stranger? Or is there a tendency for a different, independent influence of local deprivation in particular aspects - e.g. labour market or local economy, or social services, etc. - on the perception and attitudes towards immigrants? And are these influences mediated by the presence and activity of local civil society organisations?

The paper consists of four parts. In the next (second) part, after a brief review of 'spatial' approaches to the problem of migration in (interdisciplinary) 
sociological research, there are analyses of the environment-stranger issues - including attitudes towards immigrants - that can be operationalised on the basis of data from international comparative surveys. In the third part, the same type of issues / relationships are discussed on the basis of a spatial analysis of microdata from the Local Data Bank and research on migration by the Statistics Poland, focusing on the phenomenon of internal migration (between 'local communities', represented approximately by gminas), and also data from Social Diagnosis survey (data for 2015.). The explanation of the results of spatial analyses in the summary (in the fourth part) concludes the considerations in this paper.

\section{Perspectives AND Dimensions OF Migration RESEARCH IN THE EU - ATTITUDES TOWARDS IMMIGRANTS}

\section{TAXONOMY OF ANALYTICAL PERSPECTIVES IN SOCIOLOGICAL RESEARCH}

The choice of the migration process as a context for the analysis of the environment-stranger relations - interpreted in terms of the transformation of a stranger's status induced by the change in the social space - gives rise to the need to define the adopted analytical perspective, taking into account both the specificity of the spatio-sociological and the interdisciplinary nature of the explored phenomenon. In the first aspect, a taxonomy of sociological research perspectives on international migration, of a kind offered by FitzGerald can be useful (2014). There are five (sociological) analytical perspectives that can be identified according to the specification of the 'reference groups and social (phenomenon) area concerning migration', as well as the types of the trajectories of change (FitzGerald 2014: 117) - as follows:

1. the perspective of selectivity - (reference groups:) the auto-selectivity of emigrants $v i s-\grave{a}-v i s$ those experiencing deprivation (living 
in a disadvantaged situation) in the country of origin; origin and choice of destination by immigrants - divergent trajectory of change;

2. the perspective of the classic assimilation - the point of reference is the target statuses of the descendants of 'new immigrants' vis-à-vis descendants of 'old' immigrants - convergent trajectory of change;

3. the perspective of the segmented assimilation - the point of reference is the processes of assimilation of the new immigrants and their descendants vis-à-vis selected segments of the host population - divergent strategy;

4. the perspective of transnationalism - processual approach, omitting "specific" points of comparison in favour of dispersed social areas (phenomena) - reproductive trajectory of change;

5. the perspective of dissimilation - the point of reference is emigrants and their descendants vis-à-vis those experiencing deprivation (living in a disadvantaged situation) in the country of origin - divergent trajectory.

In practice, within each of the above perspectives, a mixed strategy, combining a quantitative and qualitative approaches, would be appropriate to use in the analysis of such a complex spatio-temporal phenomenon as the process of migration (Creswell, 2014). Here, it will only be possible to exemplify by the qualitative research on the phenomenon of the so-called queer diaspora (Mole, 2021).

\section{INTERDISCIPLINARY ANALYSIS OF THE MIGRATION PROCESS}

\section{AS A TRANSFORMATION OF THE STATUS OF A STRANGER}

Analysis of the multidimensional nature of the migration process as a change of local communities (spaces) inducing a transformation of the status of its subject (migrant / stranger) - includes interdisciplinary aspects of the intersecting domains, features and points of view.

It would be useful to arrange the elements of theorizing about migration in an interdisciplinary perspective, and to take into account the types of research questions specific to individual fields, along with a dominant type of theoretical orientations. Box 1 is based on such arrangement proposed by Brettelle and Hollifield (2015) with narrowing down to four disciplines - demography, 
geography, economics and sociology - considered in more or less direct way in this paper. Other disciplines, which are present in the full arrangement like anthropology, history, legal and political studies (see Brettelle i Hollifield 2015: 4) - are skipped here.

Chart 1.

\section{Theorizing about migration in an interdisciplinary perspective}

\begin{tabular}{|c|c|c|}
\hline $\begin{array}{c}\text { Discipline: } \\
\text { problems / questions }\end{array}$ & $\begin{array}{c}\text { Dominant theoretical } \\
\text { orientations }\end{array}$ & $\begin{array}{c}\text { Sample hypotheses } \\
\text { [levels of analysis] }\end{array}$ \\
\hline $\begin{array}{l}\text { Demographics: } \\
\text { processes of taking on } \\
\text { of the characteristics } \\
\text { of each other by } \\
\text { immigrants and 'natives' } \\
\text { (time) }\end{array}$ & $\begin{array}{l}\text { Migration theories (cost } \\
\text { / benefits and structural); } \\
\text { assimilation and pluralist } \\
\text { theories of integration; } \\
\text { theories of migration effects } \\
\text { (economic, other) }\end{array}$ & $\begin{array}{l}\text { Immigrants do not integrate } \\
\text { effectively while they experience } \\
\text { exclusion of 'membership'. } \\
\text { [persons, ethnic and national } \\
\text { groups, groups of foreign origin] }\end{array}$ \\
\hline $\begin{array}{l}\text { Economics: what } \\
\text { are motivation } \\
\text { for migration (?); } \\
\text { explanation of tendency } \\
\text { to migrate and its } \\
\text { effects }\end{array}$ & $\begin{array}{l}\text { Rationalist (cost-benefit) and } \\
\text { utility maximization }\end{array}$ & $\begin{array}{l}\text { Incorporation changes along with } \\
\text { the immigrant human capital } \\
\text { [micro-level, persons] }\end{array}$ \\
\hline $\begin{array}{l}\text { Geography: what can } \\
\text { explain social and } \\
\text { spatial patterns of } \\
\text { migration? }\end{array}$ & $\begin{array}{l}\text { Rational, structural and } \\
\text { transnational }\end{array}$ & $\begin{array}{l}\text { Incorporation depends of ethnic } \\
\text { networks and settlement patterns } \\
\text { [macro-, meso-, micro-level: } \\
\text { persons, households, local groups / } \\
\text { communities] }\end{array}$ \\
\hline $\begin{array}{l}\text { Sociology: how to } \\
\text { explain occurrence } \\
\text { of incorporation and } \\
\text { exclusion? }\end{array}$ & $\begin{array}{l}\text { Structuralist and } \\
\text { institutional theoretical } \\
\text { orientations }\end{array}$ & $\begin{array}{l}\text { Incorporation changes along with } \\
\text { human and social capital } \\
\text { [macro-, ethnic groups and social } \\
\text { classes] }\end{array}$ \\
\hline
\end{tabular}

Source: Based on Brettelle and Hollifield (2015:4).

Data: Quantitative approaches, both nationally and internationally, require reference to data from multiple sources. The data used in the analysis come mainly from the research of the European Social Survey, as well as the research on internal migration by Statistics Poland and the Local Data Bank, as well as the survey known as Diagnoza Społeczna (Social Diagnosis), data from the year 2015. The last three of these sources together constitute the Analytical Database $(\mathrm{ABD})$, which also contains geo-statistical data. The respective geographical coordinates enable the integration of information for the sake 
of exploration of spatial patterns (clusters) of migrations and attitudes at the level of local communities / communes (gminas). Basic objective information about the community / commune, characterizing it as a complex physical space, is provided by Multidimensional Index of Local Deprivation (MILD) ${ }^{1}$.

\section{ATTITUDES TOWARDS IMMIGRATION FROM OUTSIDE EU - POSITION OF POLAND}

The results of the European Social Survey prove great differentiation of the attitudes towards immigrants among populations of $28 \mathrm{EU}$ countries. In terms of direct expression of the attitude towards immigrants, Poland is not the most anti-migration country. It belongs to a larger group of countries of the similar profile (very positive - positive - negative - very negative), where on the top there is Hungary, Czech Republic, Latvia, Estonia, Bulgaria, Cyprus, Slovakia, and Slovenia (see. Standard Eurobarometer, November 20142018). For instance, Poland's migration policy is oriented pro-migration with clear interest in employing immigrants from neighbouring countries, mostly Ukrainian citizens, due to shortage of specialists in many key sectors of economy. "Migration can have a positive impact on the state of the population [...] . Migration has a wide impact on change in the living conditions of migrants and those among whom migrants settle." (Hrynkiewicz et al., 2019: 17). Some aspects of such general hypotheses are verified in the forthcoming studies.

The assessment of the migration impact on life in the country, according to the data from the 1st round of the ESS (2002) and the 7th round (2014), proves the high position of Poland on the scale of positive evaluation - only 4 Scandinavian countries are ahead of Poland in the favourable evaluation of the impact of immigration on life in the country; Poland is followed by Germany, Switzerland, the Netherlands and the remaining 16 countries with lower appreciation of migrants' contribution.

On the other hand, statements on the values indirectly related to the situations in which a stranger / incoming migrant usually finds himself - expressed, for example, by a statement such as: helping others and caring for their well-being is important - Poland, along with Bulgaria, the Czech Republic, Hungary, and Estonia form a group of those with much less favourable attitude, in contrast 
to the majority of countries opting for a positive attitude (Austria, Germany, Great Britain, Ireland, and Serbia) - see Figure 1.

Figure 1.

The structure of responses to the question whether helping others and caring for their well-being is important, according to countries participating in ESS-2018.

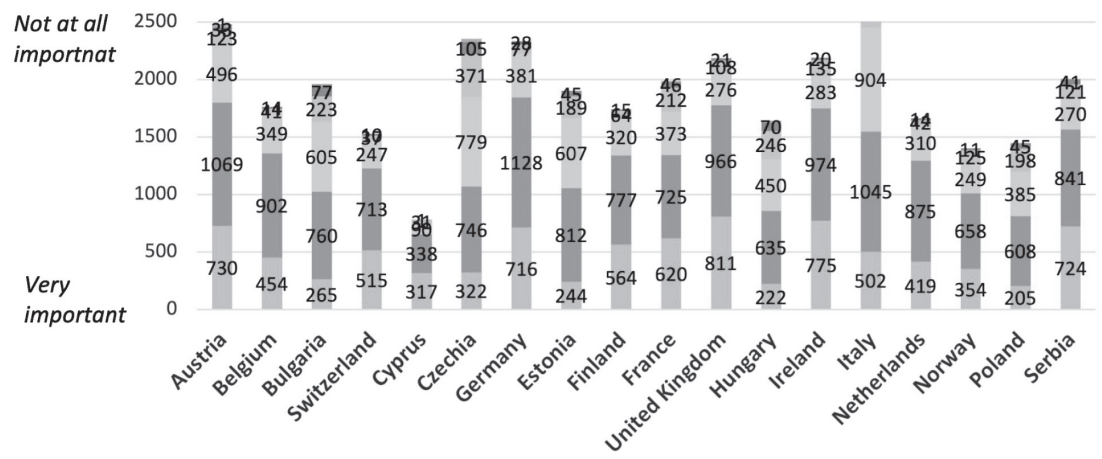

Source: Own elaboration based on data of the European Social Survey / ESS (round 9, 2018).

A closer look at the structure of statements allows us to notice that apart from a small number of countries (Hungary, Czech Republic, Bulgaria and Estonia) in other countries - including Poland - the pro-help attitude outweighs the opposite attitude, considering help to be irrelevant. Identification of the attitudes dominating in the EU countries in this aspect is particularly important in the face of the growing problem of refugees and, in general, forced immigration.

Additional analysis of the 7th ESS Round data (2014) provides initial answers to the question about dispositions to specific behaviour and attitudes, in the sense of correlates of respectively positive and negative attitudes. Relatively the most significant factors are respondents' education and income - the positive attitude of people with a higher education diploma and those belonging to the upper income quantile contrasts with the least favourable attitude towards such immigration of people without a high school diploma and those at the bottom of the income ladder. Likewise, the leading correlates of negative attitudes are age, nationality, and religion; to a lesser extent, among them there is also employment status (unemployed) and immigrants. 
In the context of the aforementioned research results the structure of responses to Fig. 2 may be somewhat paradoxical. It presents satisfaction with selected aspects of the situation in the country, starting with a sense of emotional attachment to Europe.

Figure 2.

Satisfaction with selected aspects of the situation in the country and a sense of emotional attachment to Europe, in 19 countries (ESS, 2018)

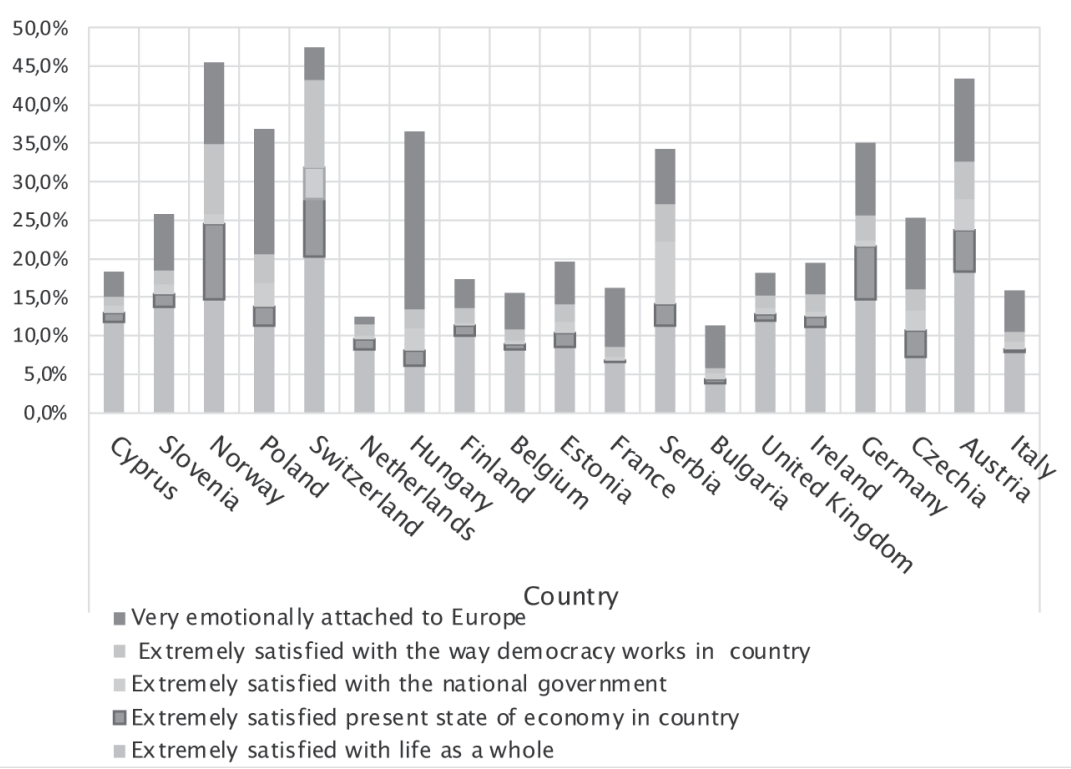

Source: Own elaboration based on data from the European Social Survey / ESS (2018).

That attachment is relatively the highest in Hungary and Poland, while having a greater share in the structure of ratings than among inhabitants of Germany or Serbia, countries next on the general scale. In Poland, the second largest type of satisfaction is satisfaction with life 'in general'. The Dutch, English, Irish, Cypriots, Finns, and Italians have relatively the lowest attachment to Europe. In general, the percentage structure of satisfaction with the selected (5) aspects of evaluation allows to compare national profiles.

The professional employment profile of immigrants from two different geopolitical zones, from EU and non-EU countries, also informs about their 
status differentiation. However, these profiles do not differ in a significant way. Personal service workers and construction workers dominate in both groups of employees (EU and non-EU); the percentage of cleaners among immigrants from EU countries is much higher, while auxiliary workers dominate among people from outside (Migration Statistics European Commission).

\section{ATTITUDE TOWARDS IMMIGRANTS AMONG VOTERS OF political parties (IN POLAND AND THE NetherlandS)}

There are two dimensions of the attitude towards immigrants that are explored in the European Social Survey 2018: the evaluations of their influence on 'economy' and on 'life in the country' indicate clear convergence between the profiles of voters' responses from specific political parties in Poland. In the Fig. 3, the first profile concerns predominance of positive over negative evaluations among supporters of the Civic Platform (Platforma Obywatelska), United Left (Zjednoczona Lewica), Together (Razem), Nowoczesna, Kukiz'15 and PSL, that are all the parties except for Law and Order (PiS) and Korwin (Fig. 3, panel A).

Figure 3.

Assessment of the impact of immigrants (A) on the economy and (B) on life in the country among supporters (voters) of political parties in Poland, according to the last parliamentary election.

A. Assessment of the impact of immigration on the economy, by political preferences / vote for political party in parliamentary elections
B. Assessment of the impact of immigration on living in the country, by political preferences / vote for political party in parliamentary elections 

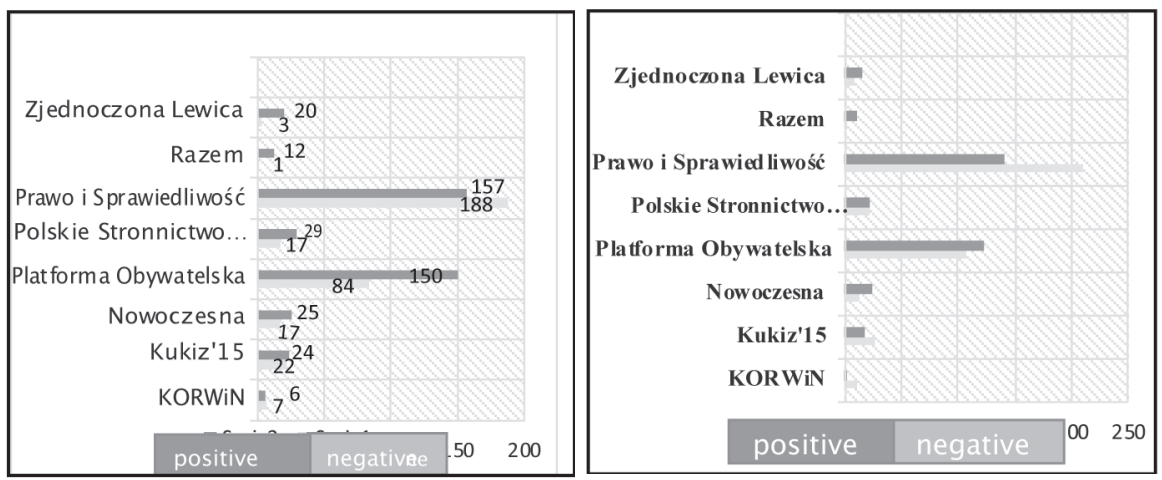

Source: Own elaboration based on data from the European Social Survey / ESS (2018).

In the second profile the only change comparing to the aforementioned attitudes concerns the shift of the Kukiz'15 supporters towards the preferences that are declared by PiS and Korwin (Fig. 3, panel B).

Another example concerns the coherence of election declarations and voting behaviour of partisan voters in the Netherland and its determinants (Scipioni et al., 2019). The correlations between the share of votes for the anti-emigration PVV party in the Netherlands (Party for Freedom of G. Wilders) and the share of migrants (growing vs decreasing) in the population provide a partial answer to the important and relevant question about the socio-demographic and economic characteristics of supporters of a certain type of attitudes towards immigrants. There are clearly distinct configurations of variants of such group-specific features for pro-immigration group and variants of the anti-immigration group, along with supporting/voting for $v s$. against the party that fights migration (PVV). The most important dependency patterns are: (i) „++" (immigration and voting for PVV) - low income people and neighbourhoods; (ii) „+-" (positive -negative) - uneducated people, without own housing, in the workforce; and (iii) „--" - young, without families, educated (supporting immigration); (iv) „, - " (against immigration, voting against PVV) - high income and ownership of high value housing (Scipioni et al., 2019: 35). The argument that the perception and evaluation of immigrants depends on the level of subjective well-being of the respondents belongs to one of the more popular arguments concerning the role of immigrants and their influence 
on the selected areas of life of the host community. Subjective well-being includes the elements classified as the symbolic-cultural (including mental) component of the social space described in the introduction. Patterns of such dependence that were identified through the Correspondence Analysis based on the ESS-2018 data are presented in Fig. 4.

All four groups of countries show similar, with unambiguous tendencies, patterns of coexistence of extreme categories on both dimensions - "high" ("low") level of subjective well-being corresponds to a "positive" ("negative") assessment of the impact of immigrants on cultural life in the country. The clear convergence of these categories allows for the conclusion that the greater the satisfaction with the achieved standard of living, the higher the tendency to take a positive stance towards the influence that strangers / immigrants have on cultural life in the country. The patterns for the group of Western and Northern, but also Eastern European countries are relatively close.

To conclude the discussion on determinants of the status of a stranger in the international context of migration processes, it is worth mentioning qualitative research on specific forms of migration. Mole's study (2021) presents a good example. It concerned queer migration, in the case of the queer diaspora from Eastern Europe (Poland and Russia), and Southern America (Brazil) to Berlin and London. The concept of a stranger takes on a new meaning while the question on how the queer spaces are created inside the ethnic diaspora communities. Among many classifications of diaspora that takes various forms, the one proposed by Vertovec is the most adequate from the point of view of the explored problem (1997): (1) 'diaspora as a social form', as community, to support national identity; (2) 'diaspora as a type of consciousness', a state of mind that means identification with the cultural heritage of the 'motherland'. N.b. in the research by Mole (2021) the Poles represent the lowest (of three ethnic groups) level of that kind of identification (ethnic) among the sexual diaspora. 
Figure 4.

The level of (subjective) well-being and the opinion on the influence of immigrants on a country's cultural life, in 26 European countries:

groups by the level of well-being:

$$
1 \text { - low, ..., } 5 \text { - high, }
$$

and by opinion on the influence in cultural domain:

1-negative, ..., 5-positive
A. Central and Eastern Europe
B. Western Europe (8 countries) (8 countries)
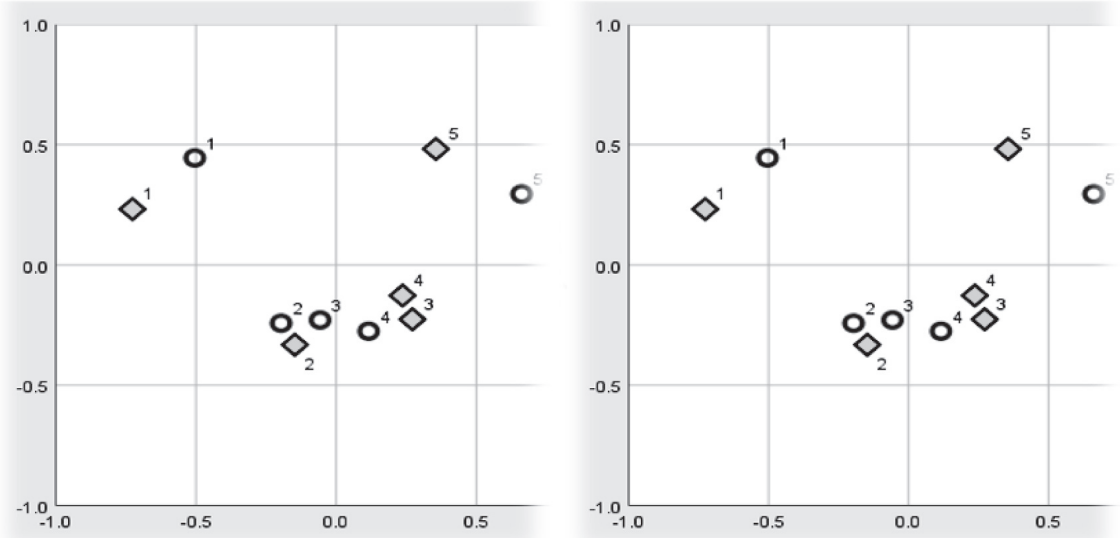

C. Southern Europe (5 countries)

D. Northern Europe (5 countries)
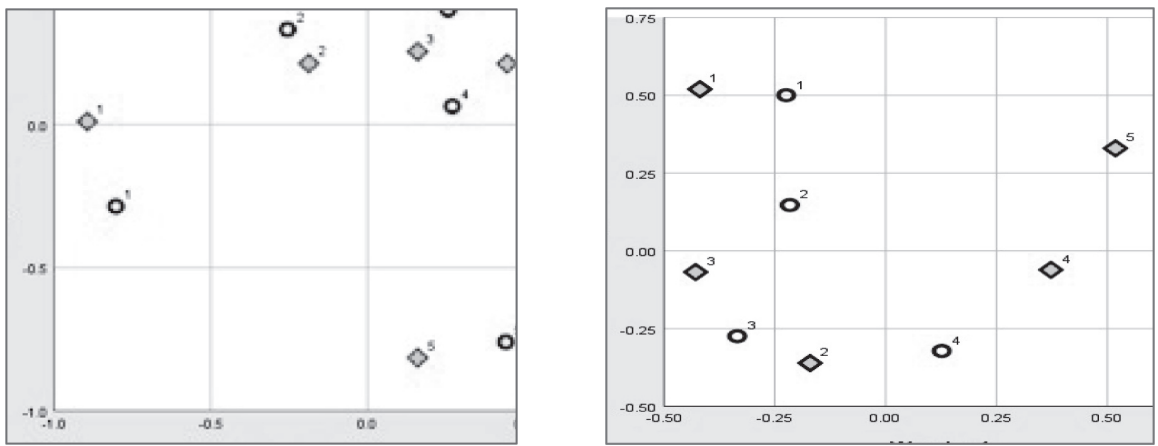

Source: Own elaboration, based on Okrasa (2019). 


\section{INTERNAL MIGRATIONS - THE MEANING OF THE 'ENVIRONMENT'}

Migration activity on the level of gmina is analysed on the basis of the data from Statistics Poland from the repository "Population. Demographic processes." Statistical information covers i.a. the intensity of migration - indicators of 'inflow' (a) and 'outflow' (b) - per 1000 inhabitants. It allows to conduct spatial analysis in terms of autocorrelation and spatial clusters as on the Fig. 5 (Okrasa, 2019).

Figure 5.

Migration activity at the level of communes - autocorrelation and spatial clusters: migration intensity - indicators of inflow and outflow per 1000 people.

\section{(a) Spatial clusters of inflow}

Moran's I: 0.315

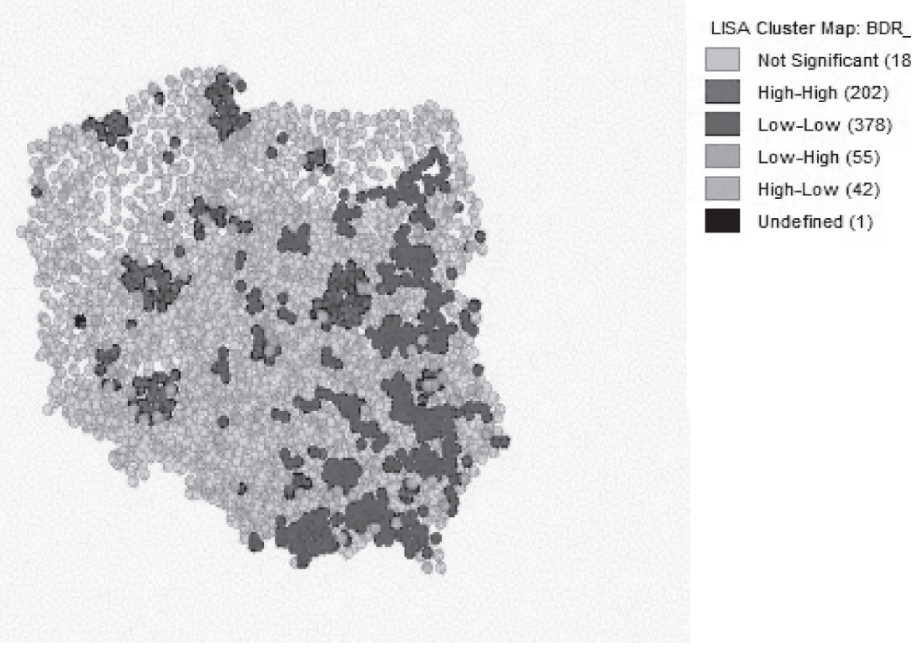




\section{(b) Spatial clusters of outflow}

Moran's I: 0.368
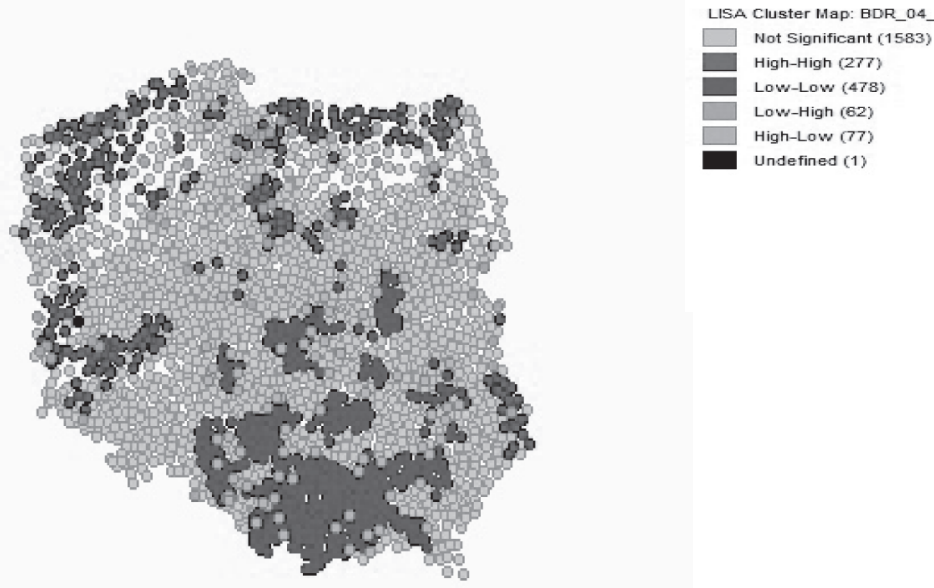

Source: Own elaboration, based on Okrasa (2019).

The distinctive spatial clusters of high (red) and low (blue) levels of migration activity on the Moran's map of the country show only a partial convergence of these two forms of activity - inflow, higher in the central-west-north part of the country than in the east-south part - and outflow - much more active in the north than in the south. Relatively high values of the autocorrelation coefficient (Moran's I) correspond to the patterns of concentration of gminas with a similar direction and intensity of spatial mobility in five outstanding agglomerations: Warsaw, Poznan, Tricity, Kraków and Wrocław (confirming the polarization model of the country's depopulation - e.g. Śleszyński, 2019). Main factors (drivers) of this mobility come from various dimensions (components of the homologous structure), including objective ecological and economic attributes (such as Multidimensional Index of Local Deprivation (MILD) or the demand for employees), the activity of 'actors' (e.g. the civil society organisations) and mental and psychological / subjective determinants of the quality of life (subjective well-being). The first aspect, that is the hypothesis 
on the dependence of the spatial intensity on the level of gmina development / deprivation, is obviously proved by the spatial cluster patterns on the Fig. $6 a .$, that refers to the immigrant inflow to gmina. The high dependence of the immigrant inflow on the low level of local deprivation is especially visible in the gminas of the Warsaw, Poznań, Wrocław, Tricity and Silesian agglomerations). And vice-versa: the inflow to eastern and south-eastern regions / gminas is low.

The relation between the outflow of emigrants and the level (under) development and derivation of the local gmina is definitely weaker and positive (Moran's I 0.08); the Silesian and Central / Warsaw agglomerations show particularly low activity. The border areas of the Lublin and Warmian-Masurian Voivodeships, probably with a 'cross-border effect' show high activity.

Figure 6.

Conditional spatial clusters of inflow and outflow of migrants depending on the level of deprivation of communes, according to the Multidimensional Index of Local Deprivation (MILD).

(a) Spatial clusters of inflow and the level of local deprivation;

Moran's I:- 0.308
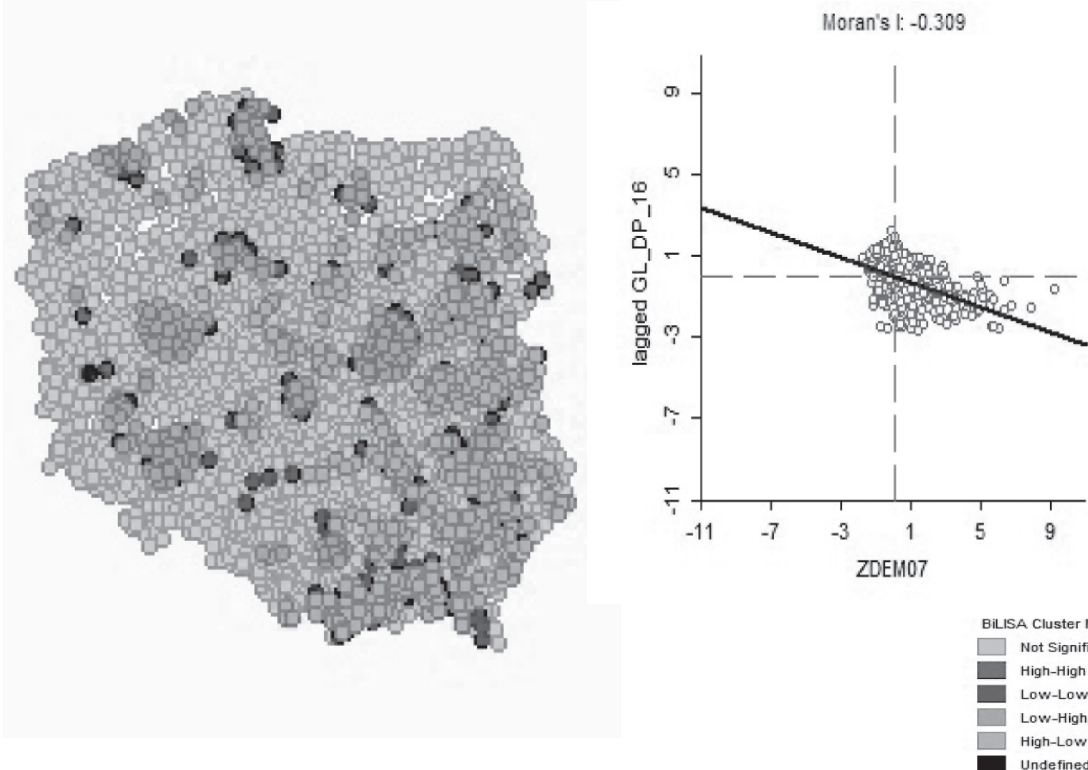
(b) Spatial clusters of outflow and the level of local deprivation; Moran's I: 0.081
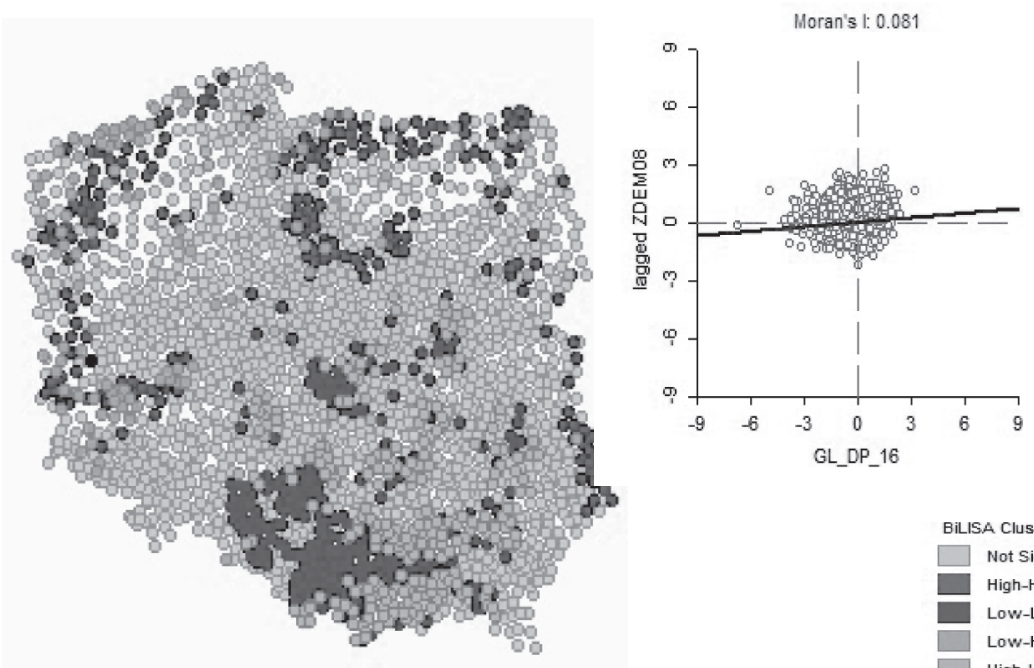

Source: Own elaboration, based on Okrasa (2019).

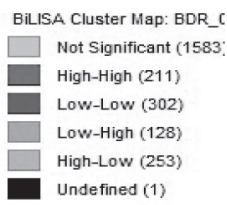

The inclusion of the subjective dimension, based on the data from the Social Diagnosis (Diagnoza Społeczna, 2015) allows to extend the above-mentioned relationship between the migration activity (inflow / outflow) and the environment (gmina), characterized by MILD, with an analogous relationship with the micro-dimension units. These units are the basic actors and inhabitants of the social space who fill it up. Nevertheless, it does not mean the direct reflection in the relations between environment and a stranger, just an important aspect of the contextualisation of these relations with individual subjective well-being of inhabitants, on one hand, and migration balance in a gmina, on the other. The results of the spatial analysis of these relationships are presented on the Fig. 7

Earlier mentioned units that come from various studies and constitute the Analytical Database were identified (and included in the base) by the geographical coordinates of a gmina. It means that in the case of sample surveys - in particular Social Diagnosis (Diagnoza Społeczna, DS) - spatial clusters are biased by inhomogeneous spatial distribution of the sample. The DS respondents were only in one third of 2,478 gminas. It obviously causes 
repercussions for the explored relations (i.e. skipping Moran's point maps), autocorrelations and spatial dependencies. Nonetheless, there is statistically significant tendencies towards positive spatial relationships, indicated by the Moran I's values.

Each of the four aspects of subjective well-being - satisfaction with the environment, with living conditions, with relationships with people and with the personal situation - is related to the favourable trends of the prevalence of inflow over outflow of migrants (not necessarily strangers). But these aspects - inhabitants' satisfaction and positive balance of migration in gmina - show the trend of the geographical co-occurrence and spatial clustering. It is worthwhile noting that activities of civil society organisations, a factor that has been omitted in this paper, is significant for the migration processes and the attitudes of their participants including newcomers (strangers) as well.

Figure 7.

Balance of internal migration - difference of inflow to and outflow from the commune - and the well-being of members of the local community / commune.

(a) Satisfaction with local surrounding. Moran's I: 0.123.

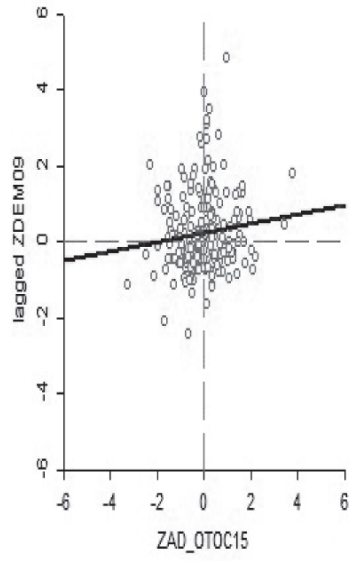

Satisfaction (b) Satisfaction with living conditions in ,own place'.

Moran's I: 0.121

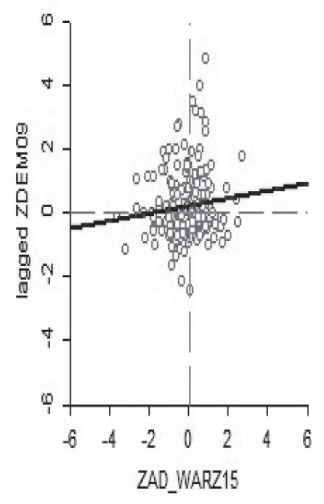

Satisfaction 
(c) Satisfaction with family relations and social relations.

Moran's I: 0.092

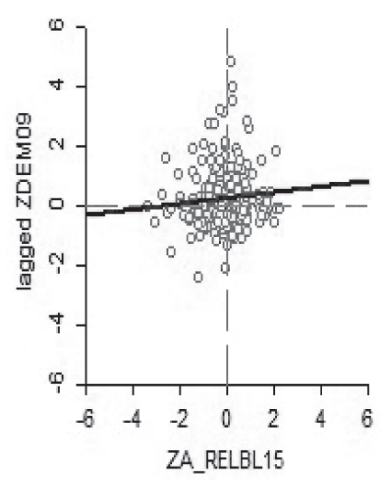

\section{Satisfaction}

(d) Satisfaction with personal life situation.

Moran's I: 0.12

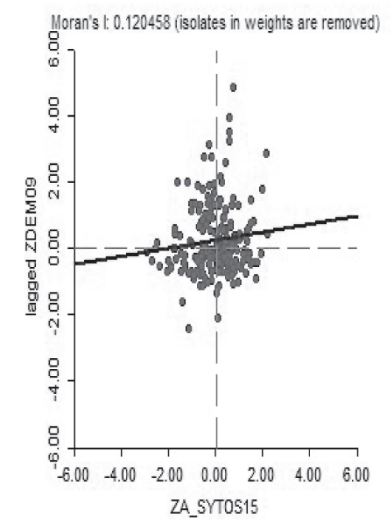

Satisfaction

Source: Own elaboration - own calculations based on data of Statistics Poland and Social Diagnosis.

Aforementioned Moran's I 0.10 suggests that such organisations are most helpful in gminas characterised by the prevalence of outflow over inflow (despite it seems counterintuitive and brings about interesting research hypothesis). 


\section{Conclusion}

Continuing the theoretical considerations taking as a starting point the concept of Pierre Bourdieu's homological structures, helpful in the operationalisation of the multi-aspect and multi-dimensional approach to the context - in which the transformation of the status of a stranger takes place through the migration process - it can be concluded that the results of the analyses generally seem to confirm the validity of employing such conceptualization. It also refers to Bourdieu's thesis that observed interactions between the objects of the migration process does not consist only of two elements and take place not only between two directly engaged parties, for example, newcomer and inhabitant ('indigenous'), but include social space as an important factor determining this relationship. At the same time not only physical characteristics that can be described by the indicators like MILD (Multidimensional Index of Local Deprivation), but elements that are characteristic for social life along with symbolic imaginations and psychological dispositions. The apparently passive role of the already existing space (by and large physical space) and the active / creative role of social space depends on the existing structures of possibilities. Interpersonal interactions that emerge along with the process embracing symbolic conceptions, values and mental states (e.g. a sense of identity / identification with a place), as well as psychological states are also important. Satisfaction is reflected in the subjective well-being measures that is significant for the migration processes and for the attitudes towards strangers and manifests itself i.e. in the attitudes favourable to immigrants' inflow. The results of the spatial analyses can also be considered from the meta-theoretical point of view as an argument for the development of spatial sociology that is especially designated to deal with this type of problems. 


\section{REFERENCES}

Bourdieu, P. (1996). Physical Space, Social Space and Habitus. Rapport 10: 1996 Institutt for sosiologi og samfunnsgeografi Universitetet i Oslo. https://archives.library. illinois.edu/erec/University\%20Archives/2401001/Production_website/pages/ StewardingExcellen.

Bourdieu, P. (1990). The Logic of Practice. Stanford, CA: Stanford University Press.

Creswell, J. W. (2017). Concise Introduction to Mixed Methods Research. SAGE Publication Inc.

Brettell, C. B., Hollifield, J. F., (Eds). (2015). Migration Theory: Talking Across Disciplines. 3rd ed. New York: Routledge.

Fischer, M., Getis, A., (Eds).(2010). Handbook of Applied Spatial Analysis. Springer.

FitzGerald, D. S. (2014). The Sociology of International Migration, In: C. B. Brettel \& J. F. Hollifield (Eds). Migration Theory: Talking across Disciplines. New York: Routledge.

Fogle, N. (2009). Social Space and Physical Space: Pierre Bourdieu's Field Theory as a Model for the Social Dynamics of the Built Environment. Dissertation. Temple University.

Frisby, D. (1994). Introduction to Simmel Texts. Theory, Culture \& Society, 11(1), 1-3 DOI: $10.1177 / 026327694011001001$.

Hrynkiewicz, J., Witkowski, J., Potrykowska, A. (2019). Migracje a sytuacja demograficzna Polski, Warszawa: Zakład Wydawnictw Statystycznych.

Mole, R. C. M.(2021). Rethinking diaspora: queer Poles, Brazilians and Russians in Berlin, In: Mole, R. C. M. (Ed.). Queer Migration and Asylum in Europe. London: UCL Press. https://doi.org/10.14324/111.9781787355811.

Okrasa, W. (2019). Migracje wewnętrzne a rozwój i dobrostan społeczności lokalnych. Eksploracja przestrzennych aspektów zależności / Internal migrations and the development and well-being of local communities. Exploration of spatial aspects of dependence. In: J. Hrynkiewicz, J. Witkowski J, A. Potrykowska, Migracje a sytuacja demograficzna Polski, , s. 117 - 136. Warszawa: Zakład Wydawnictw Statystycznych.

Okrasa, W. (2016). Obcy i przestrzeń - interakcja obcego i miejsca w przestrzeni lokalnej/ Strangers and Space. The Interaction of a Stranger and a Place in the Local Space, In: T. M. Korczyński, A. Orla-Bukowska (Eds) Obcy w labiryncie kultur. Warszawa: Warszawskie Wydawnictwo Socjologiczne.

Okrasa, W. (2014). Trzeci Sektor i Administracja Publiczna. Współdziałanie na rzecz Rozwoju Lokalnego. Raport z realizacji Projektu. Wyższa Szkoła AdministracyjnoSpołeczna w Warszawie.

Scipioni, M., Tintori, G., Alessandrini, A., Migali, S. and Natale, F.(2019). Immigration and trust in the EU, Publications Office of the European Union, Luxembourg. ISBN 978-92-76-14661-2 (online), doi:10.2760/76114 (online), JRC118855 
Standard Eurobarometer, November 2014-2018. https://www.gesis.org/en/eurobarometer-data-service/survey-series/standard-special-eb/study-overview/eurobarometer-902-za7488-october-november-2018.

Vertovec, S. (1997). Three meanings of "diaspora", exemplified among South Asian religions, Diaspora 6:277-99. https://doi.org/10.1353/dsp.1997.0010.

Śleszyński, P. (2019). Znaczenie migracji wewnętrznych w rozwoju społeczno-gospodarczym i terytorialnym Polski/ The importance of Internal Migrations in the SocioEconomic and Territorial Development of Poland. In: J. Hrynkiewicz, J. Witkowski, A. Potrykowska Migracje a sytuacja demograficzna Polski, Warszawa: Zakład Wydawnictw Statystycznych.

Urry, J. (2004). The Sociology of Space and Place, In: J. Blau (red). The Blackwell Companion to Sociology. http://www.amazon.com/The-Blackwell-CompanionSociology.

\section{ENDNOTES}

[1] Prepared on the basis of the Local Data Bank (Okrasa, 2014). Multidimensional Index of Local Deprivation (MILD) is a synthetic measure embracing 11 domains: ecology, finances, economy, infrastructure, public services, culture, housing, social assistance, labour market, education, health. 